\title{
Correction to: Characterization of the mechanical properties of human parietal bones preserved in modified larssen solution, formalin and as fresh frozen
}

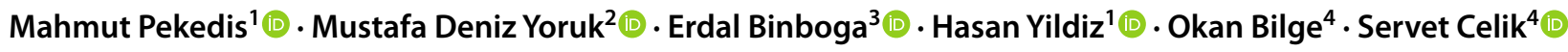

Published online: 22 July 2021

๑) Springer-Verlag France SAS, part of Springer Nature 2021

\section{Correction to: Surgical and Radiologic Anatomy https://doi.org/10.1007/s00276-021-02762-1}

In the original publication of the article, there is an error in ethical approval ID that given in "Materials and methods" and "Declarations" sections. This should be (21-6.1 T/28).

The original article has been corrected.

Publisher's Note Springer Nature remains neutral with regard to jurisdictional claims in published maps and institutional affiliations.

The original article can be found online at https://doi.org/10.1007/ s00276-021-02762-1.

Servet Celik

servetcel@yahoo.com; servet.celik@ege.edu.tr

Mahmut Pekedis

mahmut.pekedis@ege.edu.tr; mahmutpekedis@gmail.com

Mustafa Deniz Yoruk

md_yoruk@hotmail.com; denizyoruk@mu.edu.tr

Erdal Binboga

erdal.binboga@ege.edu.tr

Hasan Yildiz

hasan.yildiz@ege.edu.tr

Okan Bilge

okan.bilge@ege.edu.tr; bilgeo3@hotmail.com
1 Faculty of Engineering Department of Mechanical Engineering, Ege University, 35100 Bornova, Izmir, Turkey

2 Faculty of Medicine Department of Anatomy, Mugla Sitki Kocman University, Kotekli quarter, Marmaris road boulevard, No:50, 48000 Mentese-Mugla, Turkey

3 Faculty of Medicine Department of Biophysics, Ege University, 35100 Bornova-Izmir, Turkey

4 Faculty of Medicine Department of Anatomy, Ege University, 35100 Bornova-Izmir, Turkey 